University of New Hampshire

University of New Hampshire Scholars' Repository

$12-1994$

\title{
Climate controls on temporal variability of methane flux from a poor fen in southeastern New Hampshire: Measurement and modeling
}

\author{
Steve Frolking \\ University of New Hampshire - Main Campus, steve.frolking@unh.edu \\ P Crill \\ Stockholm University
}

Follow this and additional works at: https://scholars.unh.edu/earthsci_facpub

\section{Recommended Citation}

Frolking, S., and P. Crill (1994), Climate controls on temporal variability of methane flux from a poor fen in southeastern New Hampshire: Measurement and modeling , Global Biogeochem. Cycles, 8(4), 385-397, doi:10.1029/94GB01839.

This Article is brought to you for free and open access by the Earth Sciences at University of New Hampshire Scholars' Repository. It has been accepted for inclusion in Earth Sciences Scholarship by an authorized administrator of University of New Hampshire Scholars' Repository. For more information, please contact Scholarly.Communication@unh.edu. 


\title{
Climate controls on temporal variability of methane flux from a poor fen in southeastern New Hampshire: Measurement and modeling
}

\author{
Steve Frolking and Patrick Crill \\ Institute for the Study of Earth, Oceans, and Space, University of New Hampshire, Durham
}

\begin{abstract}
Three scales of temporal variability were present in methane $\left(\mathrm{CH}_{4}\right)$ flux data collected during a 2.5 year (mid-1990-1992) study at a small, poor fen in southeastern New Hampshire. (1) There was a strong seasonality to the fluxes (high in summer); monthly average fluxes range from $21.4 \mathrm{mg} \mathrm{CH}_{4} \mathrm{~m}^{-2} \mathrm{~d}^{-1}$ (February 1992) to $639.0 \mathrm{mg} \mathrm{CH}_{4} \mathrm{~m}^{-2} \mathrm{~d}^{-1}$ (July 1991). Annual fluxes were $68.8 \mathrm{~g} \mathrm{CH}_{4} \mathrm{~m}^{-2}$ (1991) and $69.8 \mathrm{~g} \mathrm{CH}_{4} \mathrm{~m}^{-2}$ (1992). (2) There was interannual variability; distribution of flux intensity was very different from 1991 to 1992, particularly the timing and rapidity of the onset of higher fluxes in the spring. (3) There was a high degree of variability in $\mathrm{CH}_{4}$ flux during the warm season; four successive weekly flux rates in July 1991 were $957,1044,170$, and $491 \mathrm{mg} \mathrm{CH}_{4} \mathrm{~m}^{-2} \mathrm{~d}^{-1}$. Fluxes were correlated with peat temperature $\left(r^{2}=0.44\right)$ but only weakly with depth to water table $\left(r^{2}=0.14\right.$ for warm season data). Warm season fluxes appeared to be suppressed by rainstorms. Along with methane flux data we present an analysis of this temporal variability in flux, using a peatland soil climate model developed for this site. The model was driven by daily air temperature, precipitation, and net radiation; it calculated daily soil temperature and moisture profiles, water table location, and ice layer thickness. Temperature profiles were generally in good agreement with field data. Depth to water table simulations were good in 1992, fair in 1990, and poor in the summer of 1991. Using model-simulated peat climate and correlations to methane flux developed from the field data, simulated methane fluxes exhibited the same three modes of temporal variability that were present in the field flux data, though the model underestimated peak fluxes in 1990 and 1991. We conclude that temporal variability in flux is significantly influenced by climate/weather variability at all three scales and that rainfall appears to suppress methane flux for at least several days at this site.
\end{abstract}

\section{Introduction}

One challenge to accurately quantifying methane flux from peatlands is characterizing the large variability observed in measured fluxes. This variability is both spatial, with largescale variability between ecosystems and small-scale variability within a particular habitat [Crill et al., 1991], and temporal, with seasonality of flux and shorter-period variability [e.g., Whalen and Reeburgh, 1992]. Variability in flux has been related to variability in factors that influence methane production, consumption, and transport, such as soil temperature, soil moisture, transport processes from the zone of production to the atmosphere, methanogen substrate quality and quantity, and $\mathrm{pH}$ [Crill et al., 1991; Cicerone and Oremland , 1988]. In this paper we investigate the temporal variability of flux from a single peatland and the influence of weather variability on it.

For northern peatlands (north of $\sim 40^{\circ} \mathrm{N}$ ), three scales of temporal variability are observed as follows: (1) the

\section{Copyright 1994 by the American Geophysical Union.}

Paper number 94GB01839.

$0886-6236 / 94 / 94 G B-01839 \$ 10.00$ fundamental annual signal, with high fluxes limited to the warm season, which corresponds to several factors considered important to methane flux, including warm soil temperatures [e.g., Crill et al., 1988], significant active layer thickness in permafrost zones [e.g., Whalen and Reeburgh, 1992], and high ecosystem productivity [Whiting and Chanton, 1993]; (2) interannual variability, both in summer season peak fluxes and in the timing and rapidity of the spring and fall transitions [e.g., Whalen and Reeburgh, 1992; Dise, 1993]; and (3) a short-term (week-to-week) variability during the high-flux season [e.g., Whalen and Reeburgh, 1992; Dise, 1993]. To the degree that these variabilities are controlled by weather variability, such a characterization will give insight into the potential response of wetland flux to projected changes in mean climate and climate variability and into devising methane flux assessment and monitoring schemes.

In a 4-year study of methane flux from tundralike environments in Fairbanks, Alaska, a strong seasonal signal was seen at all sites, as well as interannual variability [Whalen and Reeburgh, 1992]. Whalen and Reeburgh also report very high variability in thaw season fluxes (intraseasonal variability) at all sites, but they provide no discussion. They find the best correlation to annual flux was the mean annual temperature integral over the active layer. This type of 
parameter, however, cannot address the issue of short-term (intraseasonal) variability. In a multiyear study at several sites in Minnesota, Dise [1993] also reports a strong seasonal signal, interannual variability in this fundamental signal, and variability during the warm season flux period. A strong correlation between methane flux and peat temperature $(10$, 20 , or $30 \mathrm{~cm}$ ) describes the fundamental seasonal signal [Dise et al., 1993]. Including depth to water table in regressions of soil climate against methane flux generally did not improve the correlations significantly. Fluxes in 1989 at the Minnesota sites were generally higher than in 1990; Dise [1993] suggests that this may be due to interannual variability in climate, as both peat temperature and precipitation were greater in 1989 than in 1990.

Two hypotheses have been suggested for the high intraseasonal variability often observed in warm season fluxes at a single site. Moore et al. [1990] report significant methane flux pulses during mid-August at two of three sites in northern Quebec. They attribute these pulses to a 3-week dry period, with a consequent lowering of the water table (5-10 $\mathrm{cm}$ ). This lower water table will reduce hydrostatic pressure in the submerged peat, causing a degassing of dissolved methane, as was evidenced by reduced pore water methane concentrations [Moore et al., 1990]. The hydrostatic pressure of $10 \mathrm{~cm}$ water $\left(=980 \mathrm{~N} \mathrm{~m}^{-2} \sim 1 \mathrm{kPa} \sim 0.01 \mathrm{~atm}\right)$ is on the order of normal variations in atmospheric pressure; $2-3 \mathrm{kPa}$ drops in atmospheric pressure seem to cause a bubbling release of methane in beaver ponds ( $\mathrm{N}$. Roulet, personal communication, 1994). Windsor et al. [1992] describe two types of episodic fluxes from northern Quebec peatlands. The first occurs during spring thaw and they suggest that it is associated with the release of winter methane production trapped under the winter ice cover. The second type, brief events in midsummer, are again attributed to a falling water table. Dise [1993] also observed methane flux pulses at several sites in Minnesota, again following a period of lower precipitation and dropping water tables. However, the following year, a similar pattern of little rain and lowering water tables did not produce observed pulses. Shurpali et al. [1993], in a single-season, eddy correlation methane flux study at a different Minnesota site, report five episodic emissions of methane, each $\sim 5$ days long, with fluxes roughly double pre- and postepisodic fluxes. They attribute these flux episodes to significant drops in atmospheric pressure $(\sim 2 \mathrm{kPa})$ and falling water tables, each contributing to reduced hydrostatic pressure and degassing of dissolved pore water methane. Shurpali et al. [1993] suggest that these episodes will not occur at every low pressure event or water table decline because, following an episodic release, sufficient time must elapse to regenerate a dissolved methane pool. The episodic events observed in northern Quebec did not correlate with drops in air pressure [Windsor et al., 1992].

Below, we present multiyear methane flux data from a peatland in southeastern New Hampshire and correlations of methane flux with several environmental parameters. We then develop a model of peat soil climate driven by daily weather and compare it with measured variables. Finally, we use the model and field observations to investigate the degree of control climate/weather plays on the observed temporal variability in methane flux at this site. We also propose a third cause, precipitation patterns, for the high degree of intraseasonal variability observed.

\section{Field Study of Methane Flux}

\section{Field Site and Methods}

Sallie's Fen is a small (1.7 ha), poor fen located in southeastern New Hampshire $\left(43^{\circ} 12.5^{\prime} \mathrm{N}, 71^{\circ} 03.5^{\prime} \mathrm{W}\right), \sim 15 \mathrm{~km}$ northwest of Durham. Besides runoff from the surrounding watershed and rainfall, water enters via a small, ephemeral stream, entering in the north-northeast and exiting at the northwest side of the fen. The $\mathrm{pH}$ of the fen porewater varies between 4.2 and 5.7, with the highest $\mathrm{pH}$ values found during the spring runoff and in the northwest portion of the fen, closest to the stream entrance. The vegetation in the fen reflects its transitional state between fen and bog with both cattails (Typha latifolia L.) and sundews (Drosera rotundifolia L.) found in different parts of the fen. In general, the vegetation in the fen is dominated by Sphagnum spp., Carex spp., and ericacious shrubs, principally Chamaedaphne calyculata L., Vaccinium corymbosum L., Kalmia angustifolia L., K. polifolia Wang. and Rhododendron canadense L. Peat depths range from $\sim 1 \mathrm{~m}$ near the edge to greater than $4 \mathrm{~m}$ in the central areas.

The closest long-term meteorological station is located in Durham, New Hampshire. The 30-year (1951-1980) normal mean annual temperature for Durham is $8.1^{\circ} \mathrm{C}$, and normal mean annual precipitation is $1100 \mathrm{~mm}$. Compared with the norm $\left(14.9^{\circ}, 609 \mathrm{~mm}\right)$, the biologically active season (AprilOctober) in 1990 was cooler $\left(14.4^{\circ},-0.5^{\circ}\right)$ and wetter $(819$ $\mathrm{mm},+210 \mathrm{~mm})$, in 1991 was warmer $\left(16.2^{\circ},+1.3^{\circ}\right)$ and wetter $(776 \mathrm{~mm},+167 \mathrm{~mm})$, and in 1992 was cooler $\left(14.4^{\circ},-0.5^{\circ}\right)$ and drier $(557 \mathrm{~mm},-52 \mathrm{~mm})$. Monthly precipitation was slightly below normal in 1991 until August, when Hurricane Bob delivered more than $180 \mathrm{~mm}$ in 1 day (the monthly average for August is only $84 \mathrm{~mm}$ ). September 1991 was also a wet month. Precipitation was below normal from October 1991 through May 1992 and then above normal for June, July, and August 1992 (Figure 1).

During the period of this study, peat and air temperatures were monitored at the fen with 20 type $T$ thermocouples at depths from $50 \mathrm{~cm}$ above to $50 \mathrm{~cm}$ below the fen surface. The thermocouples were multiplexed (model AM416, Campbell Scientific, Inc., Logan Utah) and referenced to a $249 \mathrm{~kW}$ thermistor probe (model 107B, Campbell Scientific, Inc.). Rainfall and snowmelt were measured with a tipping bucket rain gauge (model TE525, Campbell Scientific, Inc.) with an accuracy of $1 \%$ at rainfalls of $5 \mathrm{~cm}$ or less per hour. After September 19, 1991, water level was monitored continuously in a $15-\mathrm{cm}$ ID well with a potentiometer connected to a float [Roulet et al., 1991]. Four other wells in the fen were measured manually at 7 to 14-day intervals during the entire study. The automated instruments were queried every minute, and the hourly average (or sum in the case of precipitation) was stored with a model CR10 data logger (Campbell Scientific, Inc.) until retrieved by phone link weekly. The met station was powered by a $12 \mathrm{~V}$ dc battery that was kept charged with a small solar power cell.

Methane flux was measured using a static chamber technique [Crill et al., 1988] at roughly 7-day to 2-week intervals at the same three sites at approximately the same time of day (midmorning) throughout the period of this study (a fourth chamber site was added in July 1992). Aluminum collars that covered $0.397 \mathrm{~m}^{2}$ were cut into the peat to a depth of $8 \mathrm{~cm}$ 

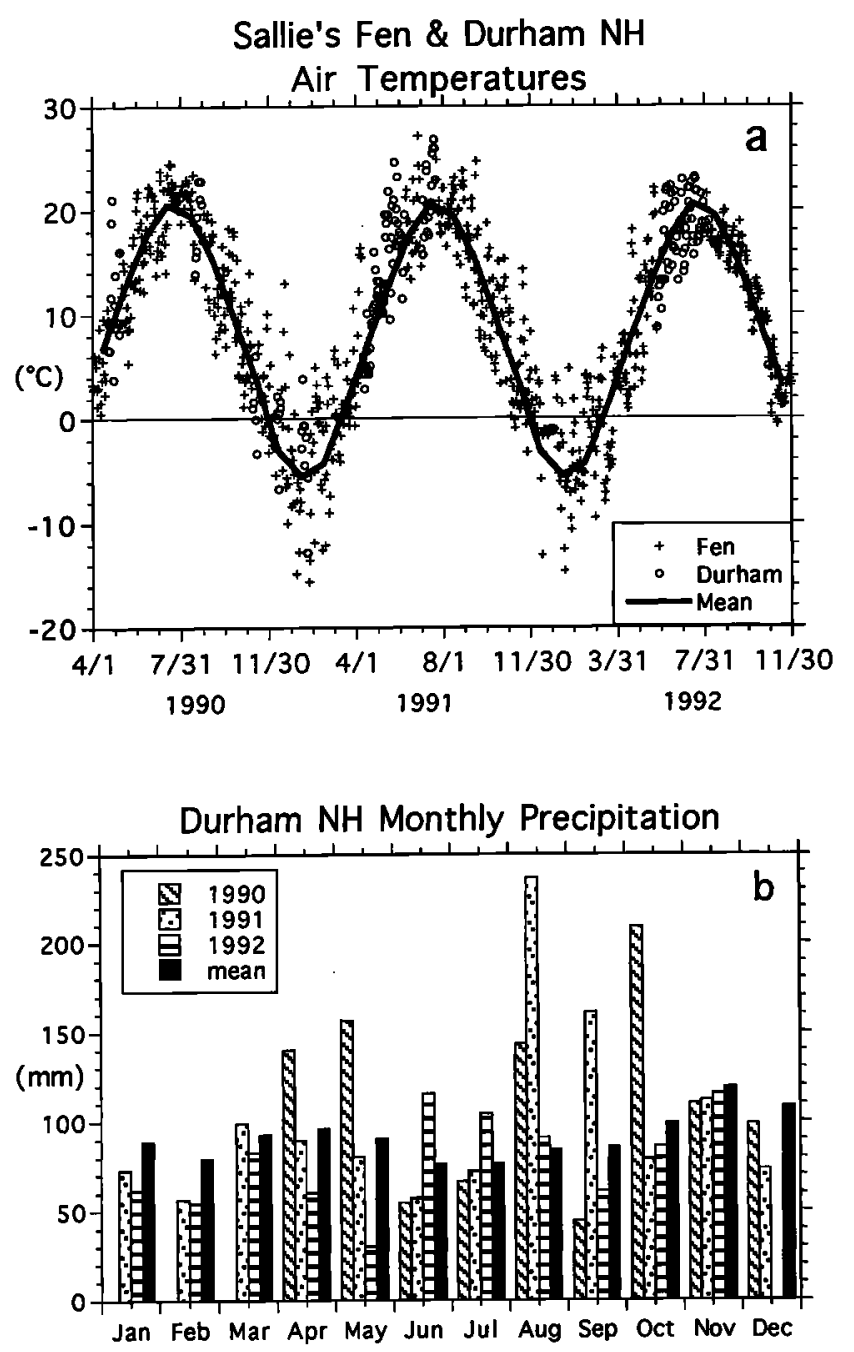

Figure 1. (a) Daily mean air temperature used in this study, measured either at Sallie's Fen (pluses) or at the National Weather Service station in Durham New Hampshire, $10 \mathrm{~km}$ from Sallie's Fen (circles). The solid line is the 1951-1980 monthly mean air temperature at Durham NH. Durham air temperatures were adjusted by $-0.56^{\circ} \mathrm{C}$, the average temperature difference from Sallie's Fen for those days when air temperature was measured at each site. (b) Total monthly precipitation and the 1951-1980 monthly averages recorded at the National Weather Service station in Durham.

during June 1989. Measurements began the next month. A welded aluminum flux chamber $(-150 \mathrm{~L}$ in volume) fit into a water-filled groove on the collar to serve as a seal. The chamber was equipped with a thermistor to measure the enclosed air temperature (to calculate internal air mass) and a brushless, battery-operated fan. The large volume was used to minimize pressure disturbances and allow larger-volume samples to be removed from the chamber. The large surface area also reduced small-scale variability and possible edge effects due to the collar.

Fluxes were measured by sealing the chamber on the collar and removing $60 \mathrm{~mL}$ aliquots of the headspace gas at 4-min intervals for $20 \mathrm{~min}$ with polypropylene syringes with siliconized polypropylene plungers. The syringes were sealed with either polycarbonate/nylon or polyethylene/nylon, three-way stopcocks. Methane samples were stable in the syringes for at least 48 hours. The samples were returned to the lab, allowed to equilibrate to laboratory temperature for 2 hours, and analyzed for $\mathrm{CH}_{4}$ and $\mathrm{CO}_{2}$ within 3 to 5 hours after collection. Samples and standards were dried across $\mathrm{CaSO}_{4}$ as they were loaded onto the injection loop. Methane was analyzed with a flame ionization detector equipped gas chromatograph (FID-GC) using $2 \mathrm{~m} \mathrm{x} 3.2 \mathrm{~mm}$ OD columns packed with Poropak Q or HayeSep Q. The carrier gas (at 30 $\mathrm{mL} \mathrm{min}^{-1}$ ) was nitrogen for the FID-GC. Peaks were quantified with Hewlett-Packard (Valley Forge, Pennsylvania) recording integrators. Secondary standards were made by calibrating two breathing air cylinders with Niwot Ridge air standards that had been prepared by P. Steele and E. Dlugokencky at the National Oceanic and Atmospheric Administration (NOAA) Climate Monitoring and Diagnostics Laboratory (CMDL) program. A $5 \mathrm{ppm} \mathrm{CH}_{4}$ standard from Scott Gas (Plumsteadville, Pennsylvania) was also used. The Scott standard was compared with the NOAA CMDL standards. Precision of analysis (standard deviation as percent of the mean of 10 to 15 daily repetitions of standard) was usually $0.2 \%$ for the 0.982 -, 1.672-, or 2.151-ppm $\mathrm{CH}_{4}$ standards. Fluxes were calculated by linear regression of the concentration changes in the five samples against time. The flux detection limit with this system was $\sim 0.1 \mathrm{mg} \mathrm{CH}_{4} \mathrm{~m}^{-2} \mathrm{~d}^{-1}$. Flux and ambient syringes were disassembled after analysis to allow syringe barrels and plungers to equilibrate with ambient air. Barrels and plungers were mixed upon reassembly.

\section{Methane Flux Results}

We chose the 1990-1992 period for analysis and to test the model for two principal reasons. First, mid-1990 was the earliest period when the data density was sufficient to meet the needs of the modeling. Second, there was significant meteorological contrast between 1991 and 1992 (Figure 1), so it would be a good test of climate influence on methane flux.

The average monthly fluxes during the study period ranged from $21.4 \mathrm{mg} \mathrm{CH}_{4} \mathrm{~m}^{-2} \mathrm{~d}^{-1}$ in February 1992 to $639.0 \mathrm{mg} \mathrm{CH}_{4}$ $\mathrm{m}^{-2} \mathrm{~d}^{-1}$ in July 1991 (July 1990 had a monthly average of 1072 $\mathrm{mg} \mathrm{CH} \mathrm{m}_{4}^{-2} \mathrm{~d}^{-1}$, but a beaver dam was removed at the beginning of the month, which may make these results anomalous for this site). The largest individual flux was $1978 \mathrm{mg} \mathrm{CH}_{4} \mathrm{~m}^{-2} \mathrm{~d}^{-1}$ measured in July 1991 (again, July 1990 had a higher value, $3562.8 \mathrm{mg} \mathrm{CH}_{4} \mathrm{~m}^{-2} \mathrm{~d}^{-1}$ which may have been influenced by the beaver dam). The annual average was the same in 1991 and 1992 at $68.8 \mathrm{~g} \mathrm{CH}_{4} \mathrm{~m}^{-2}$ and $69.8 \mathrm{~g} \mathrm{CH}_{4} \mathrm{~m}^{-2}$, respectively (1990 data were incomplete so no annual average was calculated). Sallie's Fen therefore put $1170-1186 \mathrm{~kg} \mathrm{CH}_{4}$ into the atmosphere annually when extrapolated over the area of the fen $(1.7 \mathrm{ha})$. Of the annual total, $55 \%$ is released in the summer months (July-September), $4 \%$ in the winter (JanuaryMarch), $25 \%$ in the spring (April-June), and $16 \%$ in the fall (October-December). Flux variability between chambers on a given day was often quite high (Figure 2). Coefficients of variation for the three to four chambers (standard deviation divided by mean) on a given day ranged from 0.01 to 1.52 , with a mean of 0.50 over the 32 months of the study (number of samples, $n=119$ ).

Even though the annual averages were similar between the study years, the seasonal flux distribution was different. In 


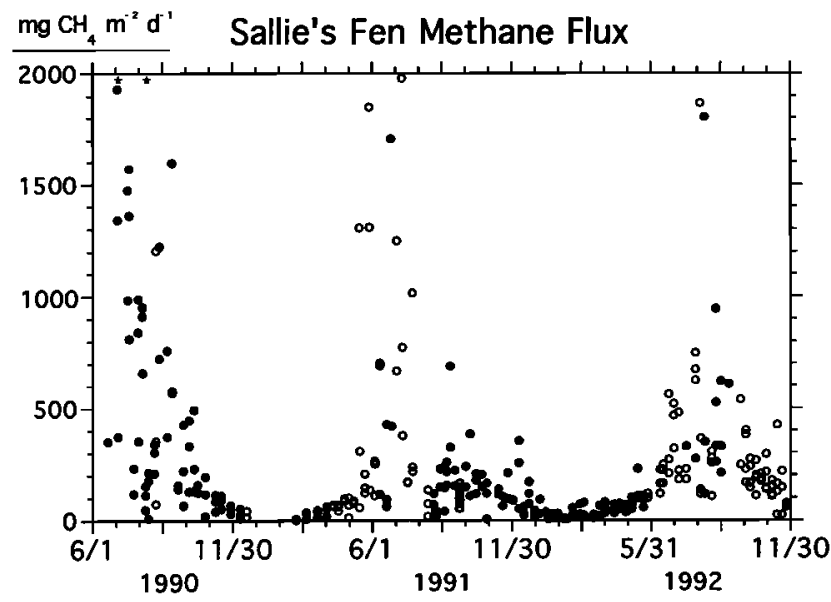

Figure 2. Methane flux time series as measured by static chambers. The chambers were at fixed locations $\sim 20 \mathrm{~m}$ apart; three chambers for 1990 through June 1992, when a fourth was added. On each sampling day (every 1 to 2 weeks) all chambers were sampled. Measurements were rejected if adequate correlations were not achieved (see text). Solid circles represent those days when peat temperature was recorded as well; only those values were used in the flux/climate regressions developed in the text. The two asterisks in 1990 mark very high flux values, $3516 \mathrm{mg} \mathrm{CH}_{4} \mathrm{~m}^{-}$ ${ }^{2} \mathrm{~d}^{-1}$ on July 17 (used in flux/climate regressions) and $3120 \mathrm{mg}$ $\mathrm{CH}_{4} \mathrm{~m}^{-2} \mathrm{~d}^{-1}$ on September 6 (not in regressions).

particular, $\mathrm{CH}_{4}$ emissions became established much earlier in 1991 than in 1992 (Figure 2). Fluxes increased very quickly after late April to peak rates in late June and early July 1991. Emissions abruptly decreased in August and stayed below 1992 levels for the rest of the season. Fluxes in 1992 displayed a more gradual increase to a peak rate in August. The August 1992 average was $16 \%$ less than the average rate during the peak month of July 1991.

Clues to the reasons for the interannual differences in fluxes may be found in examining the temperature and precipitation records for each year (Figure 1). Spring 1991 was much warmer than spring 1992, and precipitation levels were near normal, while it was relatively dry in spring 1992 . The warmer temperatures and near-normal moisture could have promoted an early and vigorous start to the methanogenic microbial community. The flooding, due mainly to Hurricane Bob in mid-August 1991, could then have suppressed methanogenic activity by washing out bacterial populations and/or substrates from the surface layers of the fen. It is also possible that a large input of $\mathrm{O}_{2}$-rich water would shift the redox potential of the pore water to higher values. The aerobic water would have to be reduced before methane production could begin again.

\section{Methane Flux Correlations to Soil and Air Climate Variables}

The effects of soil climate (dynamic profiles of soil temperature and soil water content and depth to water table) on methane flux from wetlands are often difficult to interpret.
Generally, several controlling variables are changing at the same time (e.g., rising temperature and falling water table as summer progresses). Numerous seasonal studies of methane flux in northern wetlands have found correlations between emissions and peat temperature (e.g., Crill et al. [1988], and Dise et al. [1993] in Minnesota; Bartlett et al. [1992] and Morrissey and Livingston, [1992] in Alaska; and Moore et al. [1990] in eastern Canada). However, Roulet et al. [1992] found a correlation between methane flux and temperature for only three of twenty-four sites across low boreal Canada. Svensson and Rosswall [1984] found a correlation between flux and temperature only for the wetter sites they studied in Sweden; drier zones showed no correlation. The correlation between methane flux and depth to water table (DTWT) (in our study measured in centimeters, positive down from the peat surface) is often less direct. Field studies generally find that at a single site, DTWT is only poorly correlated with methane flux, but multisite studies show that DTWT can explain some of the variation of flux between sites, with wetter sites generally emitting more methane [e.g., Roulet et al., 1992; Sebacher et al., 1986; Whalen and Reeburgh, 1990; Moore et al., 1990; Dise et al., 1993; Torn and Chapin, 1993; Fan et al., 1992]. In northern Minnesota, Dise et al. [1993] studied the direct effect of DTWT on methane fluxes by constructing three bog "corrals," $1.2 \mathrm{~m}$ square, that maintained artificially high water tables without serious disturbance to the bog ecology. They found that higher water tables enhanced fluxes. Raising the water table to the surface from its natural level of 6 to $10 \mathrm{~cm}$ deep throughout one summer doubled the season's methane flux.

Methane flux at Sallie's Fen follows a similar pattern. Using all flux data (June 1990 through September 1992) for which 12-cm peat temperature was measured (see Figure 2) a clear relationship between peat temperature $\left(T_{12}\right)$ and flux was found $\left(n=139 ; r^{2}=0.44\right.$; standard error of the estimate $(\mathrm{SEE})=$ 1.12) (Figure $3 a$ )

$$
\ln \left(\mathrm{CH}_{4} \text { flux }\right)=3.66+0.12 T_{12}
$$

Although the scatter is high, this temperature response is similar to others found in northern, high-latitude peatlands (for a review, see Bartlett and Harriss, [1993]). Using only warm season $\left(T_{12}>2.5^{\circ} \mathrm{C}\right)$ flux data (Figure $3 \mathrm{~b}$ ), little correlation was found between methane flux and DTWT, $z_{w}$ ( $n$ $\left.=68, r^{2}=0.14\right)$. This correlation showed higher fluxes for deeper water tables.

Noting that fluxes were often low soon after a rain event, methane flux was compared with a constructed variable to represent recent precipitation (weighted recent precipitation $(\mathrm{WRP}=\overline{p p t}))$

$$
\overline{p p t}=\sum_{i=0}^{4}(1-0.2 i) p p t_{i}
$$

where $p p t_{i}$ is the daily precipitation (in centimeters) $i$ days ago. This variable's impact on fluxes depends on the rainstorm's magnitude, and it will affect fluxes for 4 days after a rain occurs, but the effect falls off linearly with time. Possible explanations for this effect are discussed below. Again using warm season data $\left(T_{12}>2.5^{\circ} \mathrm{C}\right.$; see Figure $\left.3 \mathrm{c}\right)$, there is a weak relationship of lower fluxes when WRP is large 

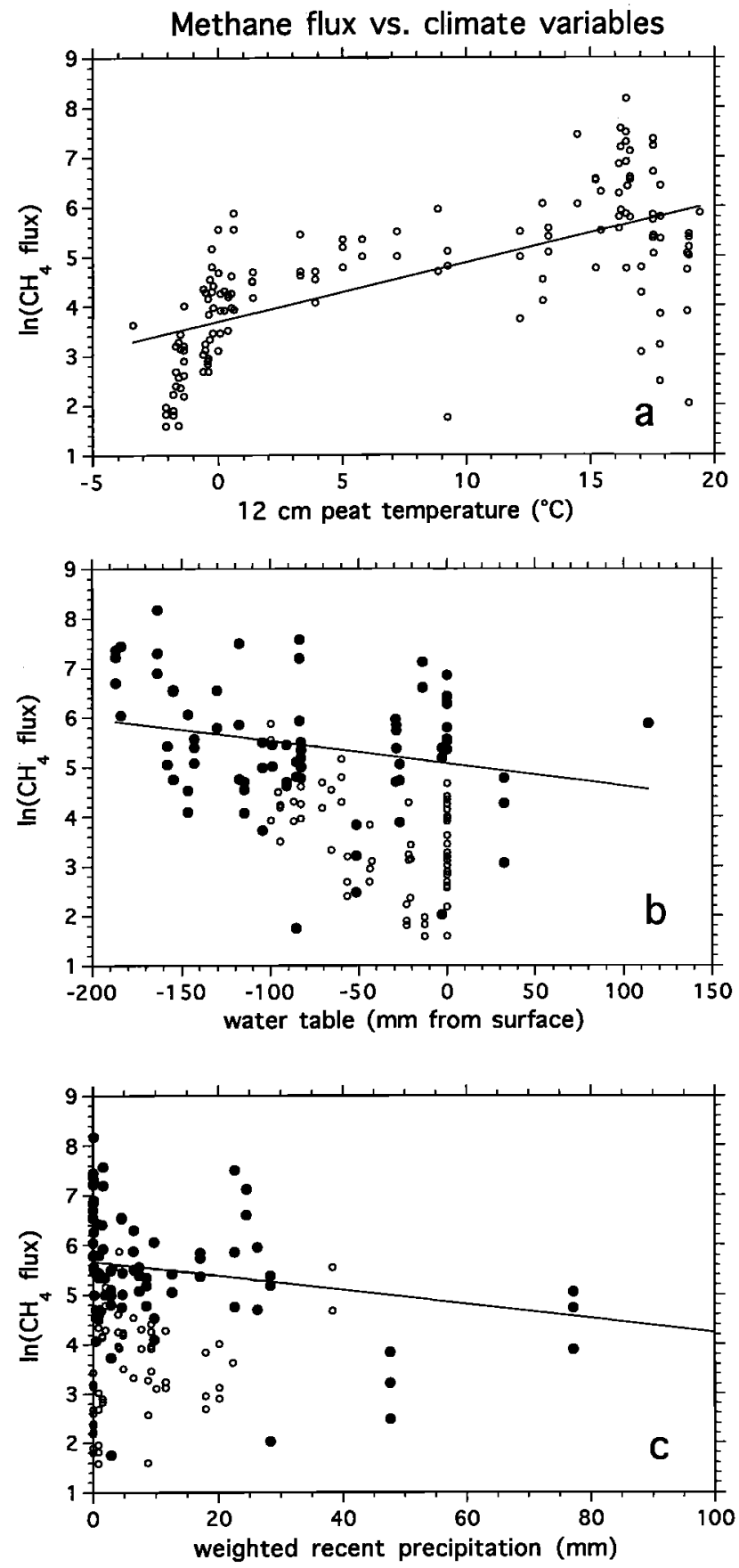

Figure 3. (a) Log methane flux (mg CH $\mathrm{CH}_{4} \mathrm{~m}^{-2} \mathrm{~d}^{-1}$ ) versus peat temperature $(12 \mathrm{~cm})$. As in other northern peatlands, there was a clear positive correlation between peat temperature and methane flux (see text for regression relationship). (b) Log methane flux versus depth to water table (DTWT). Solid circles are flux data when the $12-\mathrm{cm}$ peat temperature was $>2.5^{\circ} \mathrm{C}$; open circles are flux data when the $12-\mathrm{cm}$ peat temperature was $<2.5^{\circ} \mathrm{C}$. There was a weak correlation between DTWT (warm season, solid circles) and methane flux $\left(r^{2}=0.14\right)$. (c) Log methane flux versus weighted recent precipitation (WRP) (defined in text). Solid circles are flux data when the $12-\mathrm{cm}$ peat temperature was $>2.5^{\circ} \mathrm{C}$; open circles are flux data when the $12-\mathrm{cm}$ peat temperature was $<2.5^{\circ} \mathrm{C}$. There was a weak correlation between DTWT (warm season, solid circles) and methane flux $\left(r^{2}=0.14\right)$.
( $\left.n=78, r^{2}=0.14\right)$. WRP and DTWT were uncorrelated $(n=$ $376, r^{2}=0.05$ ).

We suspect that methane flux at Sallie's Fen is suppressed by rain and associated run-on. There are several potential mechanisms for this suppression (1) the delivery of oxygenated water to the fen surface; (2) a flushing of methanogen substrates out of the fen; (3) a flushing of dissolved methane out of the fen; and/or (4) a rising water table increasing pore water hydrostatic pressure and suppressing methane degassing. This apparent suppression of flux by rain would also contribute to the result presented earlier of higher fluxes with lower water tables. Two additional factors may contribute to the low flux/high water table correlation; first, the water table is often high in early spring and late fall (and winter) when fluxes are suppressed by cool weather, and second, when the water table is high, surface water flow through the very porous surface peat may be relatively high, continually flushing the system to some degree. Stagnant water would be more conducive to an anaerobic state. Measurements of water flow through the surface peat and $\mathrm{pO}_{2}$ in the surface water are needed to clarify this.

Multiple regressions for all combinations of $T_{12}, \overline{p p t}$, and $z_{w}$ were tried. The strongest correlation was with all three variables $\left(n=108, r^{2}=0.51, \mathrm{SEE}=1.05\right)$

$$
\ln \left(\mathrm{CH}_{4} \text { flux }\right)=3.26+0.11 T_{12}+0.083 z_{w}-0.091 \overline{p p t}
$$

Including these hydrologic variables slightly improved the correlation and introduced a greater degree of summer season variability than could be explained by temperature alone (see below).

\section{The Peat Soil Climate Model: Structure and Results}

It is clear from this and other field studies that peatland soil climate has an impact on methane flux from northern wetlands and that both temperature and moisture are likely to play a role, though with different impacts at different sites. Modeling methane flux from northern peatlands will require as a foundation a model of the peat soil climate. A physically based model of peat soil climate will allow the estimation of the biophysical drivers of peatland methane flux (in general, peat temperature and depth to water table) from widely available weather data. Numerous models of soil climate have been developed [e.g., Waelbroeck, 1993; Guymon and Luthin, 1974], as well as peatland hydrologic models [e.g., Guertin et al., 1987], but none has been specifically designed to determine temperature and moisture profiles for peatlands, with their unique thermal and hydrologic properties.

In a model of sphagnum peat development, Clymo [1984] characterized a sphagnum peat as two layered, a surface layer (or acrotelm) consisting of live and dead but uncollapsed and relatively undecomposed sphagnum and characterized by very high porosity and hydraulic conductivity and periodic aerobic conditions; and a submerged layer below (or catotelm) consisting of collapsed and partially to significantly decomposed underlying peat that is usually water saturated. The deeper layer has lower porosity and much lower hydraulic conductivity than the surface layer. We adopted this for the peat soil climate model, which consisted of two distinct 
Table 1. Bog Model Parameters

\begin{tabular}{|c|c|c|c|c|}
\hline Parameter & Value & Units & Description & Reference/Source \\
\hline \multicolumn{5}{|c|}{ Thermal } \\
\hline$z_{d p}$ & 135 & $\mathrm{~cm}$ & constant temp. depth & site field data \\
\hline$T_{\text {liq }}$ & 0.0 & ${ }^{\circ} \mathrm{C}$ & water all liquid & Williams and Smith 1989 \\
\hline$T_{\text {sol }}$ & -1.0 & ${ }^{\circ} \mathrm{C}$ & water all solid & Williams and Smith 1989 \\
\hline$z_{\text {ice }}$ & 1.0 & $\mathrm{~cm}$ & ice impermeable & ---- \\
\hline$k_{\text {org }}$ & $2.5 \times 10^{4}$ & $\operatorname{erg~s}^{-1} \mathrm{~cm}^{-1} \mathrm{~K}^{-1}$ & thermal cond., o.m. & Hillel [1980] \\
\hline$k_{\text {wat }}$ & $5.7 \times 10^{4}$ & $\operatorname{erg~s}^{-1} \mathrm{~cm}^{-1} \mathrm{~K}^{-1}$ & thermal cond., water & Hillel $[1980]$ \\
\hline$k_{\text {ice }}$ & $2.2 \times 10^{5}$ & $\operatorname{erg~s}{ }^{-1} \mathrm{~cm}^{-1} \mathrm{~K}^{-1}$ & thermal cond., ice & Williams and Smith [1989] \\
\hline$k_{\text {snow }}$ & $1.2 \times 10^{4}$ & $\mathrm{erg} \mathrm{s}^{-1} \mathrm{~cm}^{-1} \mathrm{~K}^{-1}$ & thermal cond., snow & Hillel [1980] \\
\hline$c_{\mathrm{org}}$ & $2.5 \times 10^{7}$ & $\operatorname{erg} \mathbf{c m}^{-3} \mathrm{~K}^{-1}$ & heat capacity, o.m. & Hillel [1980] \\
\hline$c_{\text {wat }}$ & $4.2 \times 10^{7}$ & $\operatorname{erg~} \mathrm{cm}^{-3} \mathrm{~K}^{-1}$ & heat capacity, water & Hillel [1980] \\
\hline$c_{\text {ice }}$ & $1.9 \times 10^{7}$ & $\operatorname{erg~} \mathrm{cm}^{-3} \mathrm{~K}^{-1}$ & heat capacity, ice & Williams \& Smith [1989] \\
\hline$c_{\text {snow }}$ & $2.5 \times 10^{6}$ & $\operatorname{erg} \mathrm{cm}^{-3} \mathrm{~K}^{-1}$ & heat capacity, snow & Hillel [1980] \\
\hline$L_{f}$ & $3.3 \times 10^{9}$ & $\operatorname{erg~cm^{-3}}$ & latent heat of fusion & Hillel $[1980]$ \\
\hline \multicolumn{5}{|c|}{ Hydraulic } \\
\hline$\eta_{a}$ & 0.90 & $\mathrm{~cm}^{3} \mathrm{~cm}^{-3}$ & surface layer poros. & Boelter \& Verry [1977] \\
\hline$\eta_{c}$ & 0.80 & $\mathrm{~cm}^{3} \mathrm{~cm}^{-3}$ & deep layer poros. & Boelter \& Verry [1977] \\
\hline$z_{\text {acr }}$ & 12 & $\mathrm{~cm}$ & surface layer depth & site field data \\
\hline$z_{b}$ & 30.0 & $\mathrm{~cm}$ & max. evap. depth & Boelter and Verry [1977] \\
\hline$z_{\text {pool,max }}$ & 5.0 & $\mathrm{~cm}$ & max. pool height & site field data \\
\hline$z_{\text {crit }}$ & 8.0 & $\mathrm{~cm}$ & max. draining depth & site field data \\
\hline$Q_{d r, \max }$ & 2.0 & cm water $\mathrm{d}^{-1}$ & max. draining rate & site field data \\
\hline$\alpha$ & 1.00 & --- & ET parameter & Rouse et al. [1987] \\
\hline$z_{E T}$ & 8.0 & $\mathrm{~cm}$ & critical evap. depth & Boelter and Verry [1977] \\
\hline$a$ & 0.05 & --- & capill. water parameter & Boelter $[1964,1969]^{\mathrm{a}}$ \\
\hline$b$ & 0.02167 & $\mathrm{~cm}^{-1}$ & capill. water parameter & Boelter $[1964,1969]^{\mathrm{a}}$ \\
\hline \multicolumn{5}{|c|}{ Snow } \\
\hline$\rho_{\max }$ & 0.30 & $\mathrm{~g} \mathrm{~cm}^{-3}$ & max. snow density & Bras $[1990]$ \\
\hline$\rho_{\min }$ & 0.05 & $\mathrm{~g} \mathrm{~cm}^{-3}$ & min. snow density & Bras [1990] \\
\hline$\partial \rho / \partial T$ & 0.025 & $\mathrm{~g} \mathrm{~cm}^{-3}{ }^{\circ} \mathrm{C}^{-1}$ & snow density parameter & site field data \\
\hline$M F_{\max }$ & 0.025 & cm water $\mathrm{h}^{-1}{ }^{\circ} \mathrm{C}^{-1}$ & snowmelt factor & Bras [1990] \\
\hline$M F_{\min }$ & 0.0125 & $\mathrm{~cm}$ water $\mathbf{h}^{-1}{ }^{\circ} \mathrm{C}^{-1}$ & snowmelt factor & Bras [1990] \\
\hline
\end{tabular}

See text for definitions of variables. Abbreviations are temp., temperature; cond., conductivity; o.m., organic matter; poros., porosity; max., maximum; min., minimum; evap., evaporation; capill., capillary.

a These values are inferred from limited data presented in the references cited, and from peat cores collected at the site.

layers, each with uniform porosity over its depth. The core of the model was one-dimensional (vertical), with no horizontal transport of heat or water within the peat. Simple run-on and runoff functions are developed to complete the water balance. All model parameter values are listed in Table 1. This model is not intended to be a predictive model of peatland soil climate for any northern peatland, although the general approach should be useful. It is intended to reproduce the peat soil climate at our study site (Sallie's Fen) and then to be used to investigate climate controls on methane flux variability.

\section{The Peat Soil Climate Model}

Modeling soil temperature: Heat transfer in peats is dominated by diffusion [Farouki, 1981; Hillel, 1980] and can be modeled by standard soil physics methods as

$$
c \frac{\partial T}{\partial t}=\frac{\partial}{\partial z}\left(k \frac{\partial T}{\partial z}\right)
$$

where $T$ is the soil temperature (in degrees Celsius), $z$ is the depth (positive down from the surface, in centimeters), $c$ is the soil volumetric heat capacity $\left(\mathrm{J} \mathrm{cm}^{-3}{ }^{\circ} \mathrm{C}^{-1}\right), k$ is the soil thermal conductivity ( $\mathrm{W} \mathrm{m}^{-1}{ }^{\circ} \mathrm{C}^{-1}$ ), and $t$ is time (in seconds). A onedimensional (vertical) model requires (1) a numerical technique for integrating the diffusion equation, (2) peat thermal properties, (3) boundary conditions, and (4) initial conditions. In addition, the model presented here had both a surface snow layer and a freeze/thaw component to track frost penetration in the winter months. 
Numerical technique. A standard numerical approach for modeling diffusion in porous media (e.g., heat in soils) is the finite element method [Huyakorn and Pinder, 1983]. A finite element code was written for one-dimensional heat diffusion using the Crank-Nicolson numerical integration technique [Press et al., 1986]. Elements were thin near the surface for higher resolution and thicker at depth where change was slower. A typical profile of element thicknesses was (from the surface down) $1.5,2.5,4,4,6,6,6,15,15$, and $20 \mathrm{~cm}$, for a total profile depth of $80 \mathrm{~cm}$. The model time step was typically $\sim 20 \mathrm{~min}$.

Peat thermal properties and freeze/thaw. Both the soil heat capacity and thermal conductivity were taken as volume-weighted, arithmetic means of the solid and liquid phases [Farouki, 1981]. Waelbroeck [1993] emphasized the importance of including freeze/thaw processes in modeling soil temperature dynamics in cold regions. As soil water freezes over a finite temperature range [Williams and Smith, 1989], the latent heat of the phase change can be considered an additional (and large) heat capacity term. In our model the soil water was assumed to freeze continuously and uniformly over a finite temperature range $\left(0^{\circ} \mathrm{C}\right.$ to $\left.-1^{\circ} \mathrm{C}\right)$. The fraction of the water that was frozen in a model element at some temperature within this range $T$ was determined as

$$
F_{\text {ice }}=\frac{T_{\mathrm{liq}}-T}{T_{\mathrm{liq}}-T_{\mathrm{sol}}}
$$

where $F_{\text {ice }}$ is the fraction of the soil water that is frozen, $T_{\text {sol }}$ is the temperature at which all soil water is frozen $\left(-1^{\circ} \mathrm{C}\right)$, and $T_{\mathrm{liq}}$ is the temperature at which all soil water is liquid $\left(0^{\circ} \mathrm{C}\right)$. Using the apparent heat capacity method [Lunardini, 1981, 1988], the soil thermal properties were given by

$$
\begin{gathered}
c=(1-\eta) c_{\text {org }}+\eta S\left(\left(1-F_{\text {ice }}\right) c_{\text {wat }}+F_{\text {ice }} c_{\text {ice }}\right)+\frac{L_{f}^{*}}{T_{\text {liq }}-T_{\text {sol }}} \\
k=(1-\eta) k_{\text {org }}+\eta S\left(\left(1-F_{\text {ice }}\right) k_{\text {wat }}+F_{\text {ice }} k_{\text {ice }}\right)
\end{gathered}
$$

where $c$ is the volume heat capacity, $k$ is the thermal conductivity, $\eta$ is the soil porosity, $S$ is the fractional waterfilled pore space, ( $1 \geq S \geq 0$ ), the subscripts refer to the solid (organic matter or ice) and liquid (water) components of the soil, and $L_{f}^{*}$ is the latent heat of fusion for water $\left(333 \mathrm{~J} \mathrm{~g}^{-1}\right.$ ) when the peat temperature is in the freeze/thaw range and zero otherwise. Total profile ice thickness was calculated as the sum of each model layer's ice content, including only those layers with ice content greater than $20 \%$.

Boundary conditions. Input weather data for the peat temperature model included daily average air temperatures. The surface boundary condition adopted assumed that the soil surface temperature (skin temperature) was approximately equal to the local air temperature. (We observed for daily means that $\left.T_{\text {surf }}=0.03+0.97 T_{\text {air }} ; n=682 ; r^{2}=0.85\right)$. This temperature was applied to the first model node $(z=0 \mathrm{~cm})$. The boundary condition at the bottom of the modeled soil profile is given by the heat flux resulting from the temperature gradient between the bottom node and the mean annual air temperature at a fixed depth below the modeled profile. To capture the seasonal ice thickness, this depth was set at 135 $\mathrm{cm}$ below the peat surface.
Initial conditions: The peat profile was initialized in early spring (April 1) to a uniform temperature of $1^{\circ} \mathrm{C}$.

Modeling the depth to water table and unsaturated zone soil moisture: Unlike mineral soils, there is only a very small and scattered data set on peat hydraulic properties [e.g., Chason and Siegel, 1986], so it is not possible to derive reliable, generic parameterizations for relationships required by standard soil moisture models [e.g., Hillel, 1980], such as peat specific water yield and hydraulic conductivity as a function of water content. In general, the submerged layer (deep, partially decomposed peat) has fairly low hydraulic conductivity. However, peats are generally saturated at depth; water movement there is probably very slow [Romanov, 1968]. The near-surface peat hydraulic conductivity is very high [Boelter and Verry, 1977], so infiltration and vertical water movement are rapid and peat water is probably rarely far from hydrostatic equilibrium. The peat behaves more like a sponge than a soil. We therefore adopt a one-dimensional (vertical) "bucket" and water balance model for the peat hydrology. At each time step the soil water balance was calculated (change equals inputs minus outputs), and then the soil water was distributed in the peat profile, and depth to water table and unsaturated zone soil water content were determined. Water movement in the peat was not simulated.

On the basis of a preliminary analysis of the hydrologic properties of several peat cores, the peat water content above the water table (unsaturated zone) was modeled as

$$
S(z)=a+b z
$$

where $z$ is the depth within the peat. Below the water table, $S$ $=1.0$. Thus the peat had a rapid dewatering at weak tension and weak capillarity [Boelter, 1964, 1969]. The total water content of the peat profile to depth $z b$ would be

$$
W_{t}=\int_{0}^{z} \eta(z) S(z) d z
$$

where the porosity $\eta$ is a function of $z$ in that it can have different values in the surface layer and the deeper layer, and $z_{b}$ is the maximum water table depth (taken as $30 \mathrm{~cm}$ ). Since $S(z)$ is a simple polynomial, (9) was integrated and inverted to give a quadratic function for the water table depth as a function of total profile water content. After the water balance for each time step was solved the water table depth was calculated from this quadratic equation and the unsaturated zone water content profile was determined from (8).

Water inputs and outputs. For a true ombrotrophic, domed bog, virtually all water movement is vertical, so water inputs would be simply precipitation and snowmelt, and water loss would be through evaporation and transpiration. For a peatland with a connection to a regional watershed (e.g., a fen) there are also potential water inputs due to stream flow, groundwater inflow, and surface water flow or seepage. There can also be water loss due to stream outflow and/or groundwater outflow.

Precipitation and snowmelt: Daily precipitation (snow reported as liquid water content) was part of the input data set (along with air temperature and net radiation); snowmelt was calculated as a function of air temperature and time of year (see below). 
Evaporation water loss: Since sphagnum vegetation is short and a sphagnum terrain is relatively smooth, it will have a relatively high resistance to turbulent exchange with the atmosphere, and it is likely that available energy will dominate evaporative losses, rather than vapor pressure deficit and turbulent mixing due to wind [Romanov, 1968]. Evaporation losses were calculated in the model using the Priestley-Taylor equation [Rouse et al., 1977]

$$
P E=\alpha\left(\frac{\Delta}{\Delta+\gamma}\right)\left(R_{\text {net }}-Q_{\text {soil }}\right)
$$

where $P E$ is the potential (maximum evaporation, $\mathrm{mm} \mathrm{d}^{-1}$ ), $\alpha$ is a parameter (taken as 1.0, based on the work of Rouse et al. [1987]), $\Delta$ is the slope of the saturation water vapor pressure curve at the local air temperature, $\gamma$ is the psychrometric constant $\left(66 \mathrm{~Pa}{ }^{\circ} \mathrm{C}^{-1}\right), R_{\text {net }}$ is the net radiation, and $Q_{\text {soil }}$ is the heat flux into the soil, which is generally a small fraction of the net radiation (assumed to be zero for this calculation [Rouse, 1984]). If net radiation data were unavailable, then daily evaporative demand was calculated with the air temperature-based Thornthwaite equation [Dunne and Leopold, 1978]. A comparison of both evapotranspiration (ET) methods for days when data were available showed that the Priestley-Taylor method was more variable and generally gave a higher value (average of $0.9 \mathrm{~mm} \mathrm{~d}^{-1}$ over $\sim 400$ days). If the air temperature or the net radiation was less than zero, then evaporative losses were set to zero. Since peat can only wick water up to a certain height and only with increasing difficulty as the water table drops [Boelter and Verry, 1977], evaporative loss was reduced from the total demand as the water table drops. This was modeled as

$$
E=\left\{\begin{array}{l}
P E \quad \text { if } z_{w}<z_{E T} \\
P E\left(\frac{z_{w}-z_{b}}{z_{E T}-z_{b}}\right) \quad \text { if } z_{w} \geq z_{E T}
\end{array}\right.
$$

where $E$ is the actual evaporative water loss, $z_{w}$ is the water table depth, and $z_{E T}$ is the water table depth at which evaporation begins to fall from its maximum value (taken as 8 $\mathrm{cm})$.

Run-on: Without a watershed hydrological model, run-on was modeled as a simple function of precipitation and an estimate of the regional water balance. For 4 days following a rain event, model run-on was given by

$$
R=0.1(p p t-0.25)\left(\frac{\text { totwat }}{\text { watcap }}\right)
$$

where $R$ is the daily run-on (in centimeters), ppt is the rainstorm's precipitation (in centimeters, note that run-on is zero if $p p t<0.25 \mathrm{~cm}$ ), totwat is the current bucket water content (in centimeters), watcap is the bucket water content at saturation (in centimeters). The ratio (totwat/watcap) is a simple simulation of the effect of the regional water balance; if the water table was low, it is likely that the region was dry and more of the water in a storm would have been held and used by the surrounding area of the watershed and less would have flowed into the fen. More than 4 days after a storm, run-on was considered negligible. The only field data from the fen to calibrate these factors were depth to water table data [Frolking, 1993].

Runoff water loss. Runoff was modeled as a drainage that depended on the depth to the water table. Water was allowed to pool over the sphagnum to $5 \mathrm{~cm}\left(z_{\text {pool,max }}\right)$. Water drained from the profile at a maximum rate when the water table was at this maximum pool height (any water inputs above this maximum were assumed to be immediately lost). As the water table dropped from this maximum value, the drainage $Q_{d r}$ fell to zero as the water table reached a depth of 8 $\mathrm{cm}\left(z_{\text {crit }}\right)$. Drainage was more rapid when the water table was near maximum and was given by

$$
Q_{d r}=Q_{d r, \max }\left(\frac{z_{w}-z_{\text {crit }}}{z_{\text {pool,max }}-z_{\text {crit }}}\right)^{2}
$$

where $Q_{d r \text {, max }}$ is the maximum drainage rate and $z_{\text {crit }}$ is the depth at which drainage stops (model parameters). As with run-on, the only field data for parameterization were the depths to water table. Two storms in November 1991 (when evaporation would be quite low) provided the basis for the runoff parameterization [Frolking, 1993].

Role of ice in bog model hydrology. The minimum ice thickness to have a hydrological impact $\left(z_{\text {ice }}\right)$ was set at 1 $\mathrm{cm}$. At that point the ice layer becomes impermeable and any liquid water inputs pool on top of the ice. The water table was then considered to be either the top of the ice layer or the surface of the pooled water, if any existed.

Modeling the snowpack and snowmelt: Precipitation was considered to be all snow if $T_{\text {air }}<0^{\circ} \mathrm{C}$ and all rain if $T_{\text {air }} \geq 0^{\circ} \mathrm{C}$. Snowfall density was a function of air temperature [Bras, 1990], calculated as

$$
\rho=\min \left(\rho_{\max }, \max \left(\rho_{\min }, \rho_{\max }+\frac{\partial \rho}{\partial T} T_{\mathrm{air}}\right)\right)
$$

where $\rho$ is the snow density $\left(\mathrm{g} \mathrm{cm}^{-3}\right), \rho_{\min }$ and $\rho_{\max }$ are maximum and minimum allowable densities, and $\partial \rho / \partial T$ is a rate of change of density with air temperature $\left(\mathrm{g} \mathrm{cm}^{-3}{ }^{\circ} \mathrm{C}^{-1}\right)$, and ' $m a x$ ' and ' $m i n$ ' are functions which choose the maximum or minimum of values within their brackets. Depth of snowfall was determined by the amount of liquid precipitation and the snow density. Snowmelt was determined by air temperature and day of year only, following the work of E.A. Anderson, as discussed by Bras [1990].

$$
\begin{aligned}
Q_{\text {melt }}= & 0.5 T_{\text {air }}\left[\left(M F_{\max }+M F_{\min }\right)+\right. \\
& \left.\left(M F_{\max }-M F_{\min }\right)\left(1+\sin \left(2 \pi\left(d_{i}+81\right) / 365\right)\right)\right]
\end{aligned}
$$

where $Q_{\text {melt }}$ is the snowmelt per hour, $M F_{\max }$ and $M F_{\min }$ are snowmelt parameters, and $d_{i}$ is the day of the year (January $1=$ 1). If $T_{\text {air }}$ was less than $0^{\circ} \mathrm{C}$, then no snowmelt occurred. When a snowpack "existed" for the model (depth $\geq 1 \mathrm{~cm}$ ), the thermal submodel added a snow layer and assigned the air temperature to the snow surface rather than the peat surface. Snowpack effect on the albedo was not modeled but was assumed to be reflected in the local air temperature. Snowmelt water was a direct input into the bucket water balance. Snow thermal properties (heat capacity and thermal conductivity) were considered constant. 


\section{Soil Climate Model Results}

Model input data. The peatland soil climate model required daily average air temperature, daily precipitation, and, if available, total daily net radiation data. Owing to instrument problems, there were several large gaps in the temperature data (see Figure 1a). The net radiometers were not installed until September 1991. Data necessary for driving the model were obtained at the fen, and if unavailable there, from the Durham weather station, $\sim 15 \mathrm{~km}$ from Sallie's Fen, operated by the National Weather Service (NWS). No net radiation data was collected at Durham during this study period, so for days when net radiation data were missing at Sallie's Fen, the Thornthwaite method of calculating potential ET was used. Fen daily air temperature $(5 \mathrm{pm}$ to $5 \mathrm{pm}$, to match the NWS data) was calculated as either the average of the warmest and coldest hourly temperatures recorded at the fen or as the daily average air temperature in Durham minus $0.56^{\circ} \mathrm{C}$. This correction is the average deviation between Durham and Sallie's Fen daily air temperatures for $300+$ days when air temperature was measured at both sites (no seasonality was observed). The tipping bucket gage installed at Sallie's Fen recorded only liquid precipitation or snowmelt from snow collected in the funnel. Therefore snowfall precipitation was taken from the Durham record (as snowfall water content) and obvious snowmelt readings in the Sallie's Fen record were set to zero. If the Durham precipitation value was reported as "trace," then it was set to $0.254 \mathrm{~mm}$ water.

The model simulation period is April 1, 1990 through September 20,1992 . The model was initialized with a uniform peat temperature of $1^{\circ} \mathrm{C}$ and an initial bucket water content of $22.7 \mathrm{~cm}$ of water, to give a water table depth of $3.2 \mathrm{~cm}$. Model parameter values are listed in Table 1.

Water table results. For the period April 1, 1990 to September 20, 1991, field DTWT data (approximately weekly values) were the average of measurements at four wells; from October 1, 1991 on, there was also continuous monitoring at a single well (hourly averages of once-a-minute measurements were recorded on a data logger; these were averaged into daily values). In mid-July 1991 the DTWT in the field was $\sim 31 \mathrm{~cm}$ (Figure 4); $30 \mathrm{~cm}$ was chosen as the maximum DTWT in the model. In the summer of 1992, DTWT was generally $\sim 5$ to 15 $\mathrm{cm}$. Water table values when the fen was frozen, roughly midDecember 1991 through March 1992, were not reliable; the instrument float was frozen in place, and the model was reporting the ice surface and possible overlying melt water. The extremely high water table values in the early summer of 1990 were due to a beaver dam, which was removed at the beginning of July 1990 . After this period the model captured the basic water table dynamics for most of 1990 and 1992 and completely missed the observed drop in water table during the summer of 1991 (Figure 4).

The water table at Sallie's Fen reflects a larger watershed ( $40 \mathrm{ha})$. One possible explanation for the very different water table behaviors of 1991 and 1992 is that in 1991, with a very warm and slightly dry spring and early summer, the regional water balance was negative and the watershed water table was low. The model, which begins to restrict water loss when the water table drops below $8 \mathrm{~cm}$ [e.g., Boelter and Verry, 1977], may have underestimated this regional drying. In 1992 the spring and summer were relatively cool and,

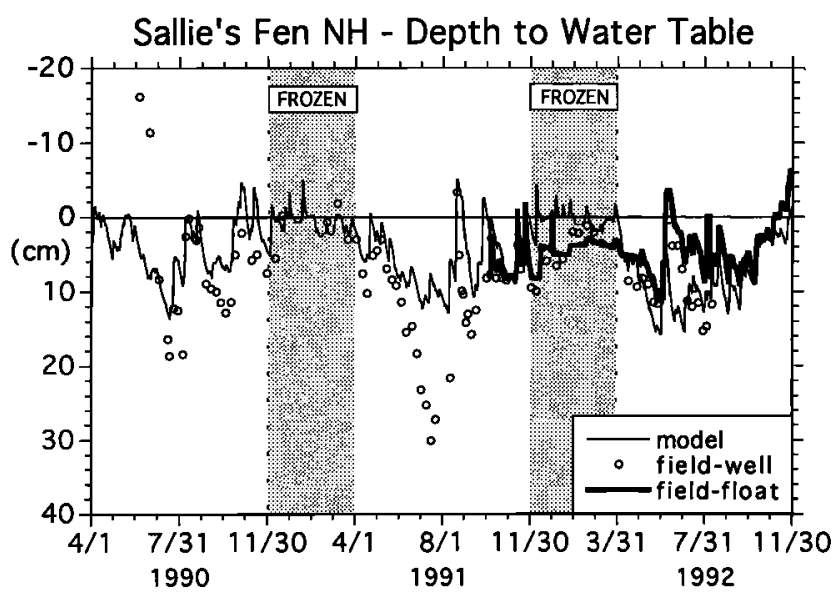

Figure 4. Field (open circles and thick, solid line) and model (thin, solid line) depth to water table (positive values imply water table below peat surface). Large differences in field DTWT between 1991 and 1992 were not simulated by the model. The very high (positive) values in 1990 were due to a beaver dam that was removed at the beginning of July 1990 . The shaded regions are roughly when the peat was frozen at the surface; at those times, water table measurements were unreliable.

although precipitation in April and May was below normal, June and July were above normal, so the regional water balance was probably more neutral. The model did not have a sophisticated coupling to the local watershed. In addition, the model used the Thornthwaite method for determining evaporative demand in 1991. When compared with the Priestley-Taylor method in 1992, the Thornthwaite method generally predicted less demand. Perhaps using the PriestleyTaylor method in 1991 would have enhanced model water loss, though probably not to the degree observed in the field. Another possible cause of some of the divergence between the model and the field is that model precipitation was based on a single point measurement, while the fen water balance is driven by the mean watershed precipitation, which sometimes may be poorly represented by a single point measurement [e.g., Dunne and Leopold, 1978].

Temperature results: Simulated peat temperatures (1991 and 1992) are compared with field values for $4 \mathrm{~cm}, 12 \mathrm{~cm}$, and $18 \mathrm{~cm}$ in Figure 5 . There were several gaps in the field data due to instrumentation problems. Overall, the model captured the seasonal signal quite well at all depths. It also captured the patterns of oscillations superimposed on the annual signal by passing cold and warm fronts. The major discrepancies between field and model peat temperatures at all depths occurred during August through November 1991, when the model peat temperature cooled more slowly and oscillated less then was observed. During the summer of 1991 the model water table was around $10 \mathrm{~cm}$ below the surface, while the field water table was measured as low as $30 \mathrm{~cm}$, so the model overestimated peat water content over the top $20-30 \mathrm{~cm}$. A higher water content enhanced peat thermal diffusivity [Hillel, 1980] and caused the model to transfer too much summer heat into the deeper peat. In the fall of 1991 both model and field water tables were similar, but the model profile had more heat 


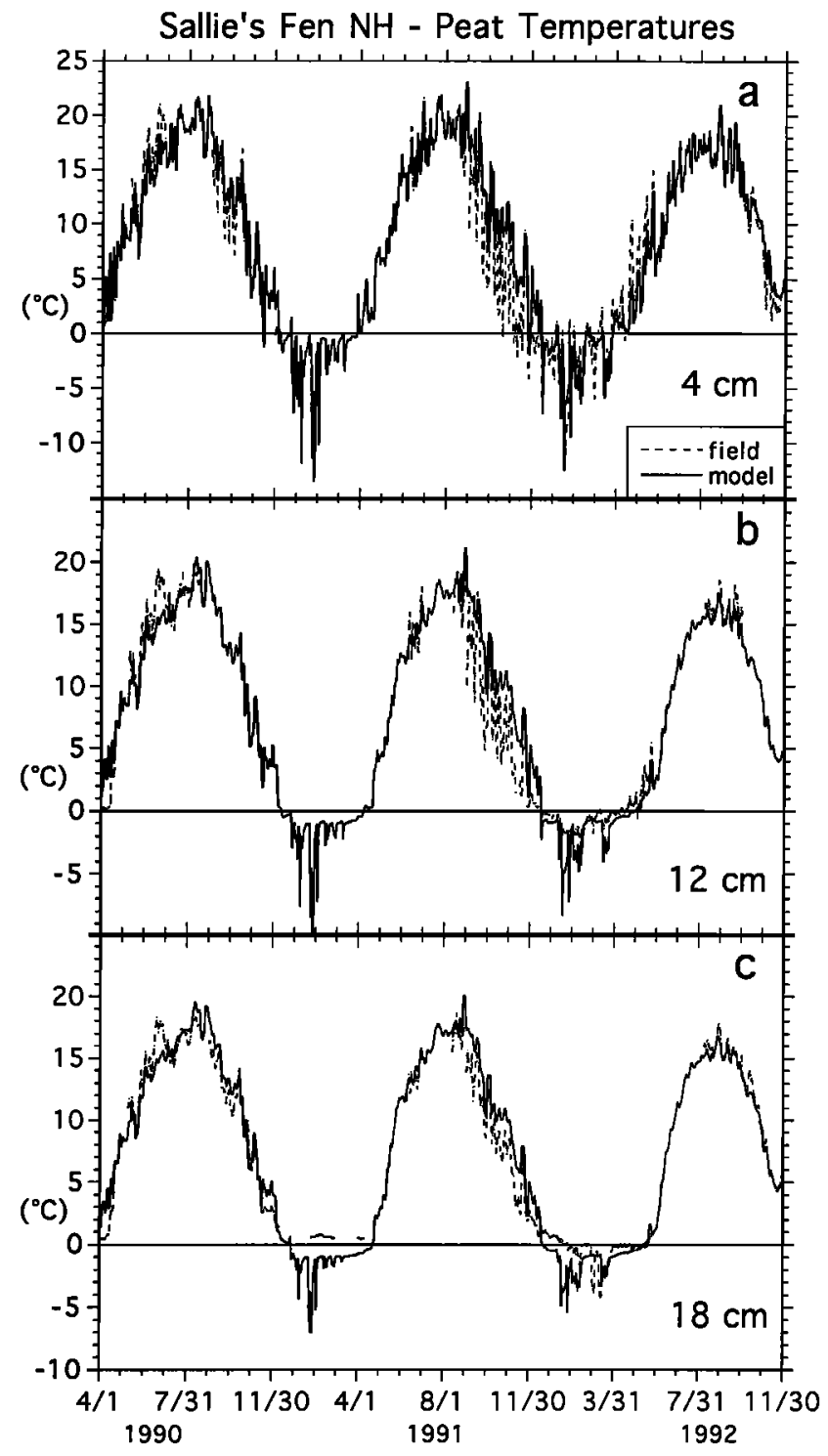

Figure 5. Field and model peat temperatures at (a) $4 \mathrm{~cm}$, (b) $12 \mathrm{~cm}$, and (c) $18 \mathrm{~cm}$. There were gaps in the field data. Model results were quite close to field results except during the latter part of 1991 when the model soil was too warm. During the summer of 1991 the model underestimated depth to water table (see Figure 3), increasing the peat water content and thermal diffusivity and, therefore, probably overestimating heat flux into the peat.

to lose and hence cooled more slowly. In 1992, when the model field water tables were much closer to field values, model and field temperatures were quite close at all depths.

\section{Model Assessment of Methane Flux Variability}

Three scales of temporal variability in methane flux were observed in the field data (Figures 6 and 7; see also Figure 2) as follows: a strong seasonality, with high fluxes in the warm months; an interannual variability, with peaks fluxes and season lengths varying from 1991 to 1992; and an intraseasonal variability, with rapid and strong oscillations in flux strength observed during the warm season.
Daily simulated methane fluxes were calculated by simulating the daily mean $12-\mathrm{cm}$ peat temperature, WRP, and DTWT, and using (3) to estimate the natural log of the methane flux $\varphi$. Approximately one-third of the field flux values were used with field temperature, DTWT, and WRP values to generate the regression (see Figure 2). The daily mean flux rate $\Phi\left(\mathrm{mg} \mathrm{CH}_{4} \mathrm{~m}^{-2} \mathrm{~d}^{-1}\right)$ was determined as

$$
\boldsymbol{\Phi}=e^{\left(\varphi+\sigma^{2} / 2\right)}
$$

where $\sigma^{2}(=1.09)$ is the variance of the simulated $\varphi$, following Baskerville [1972] and Beauchamp and Olson [1973]. Simulated fluxes were compared with mean field flux

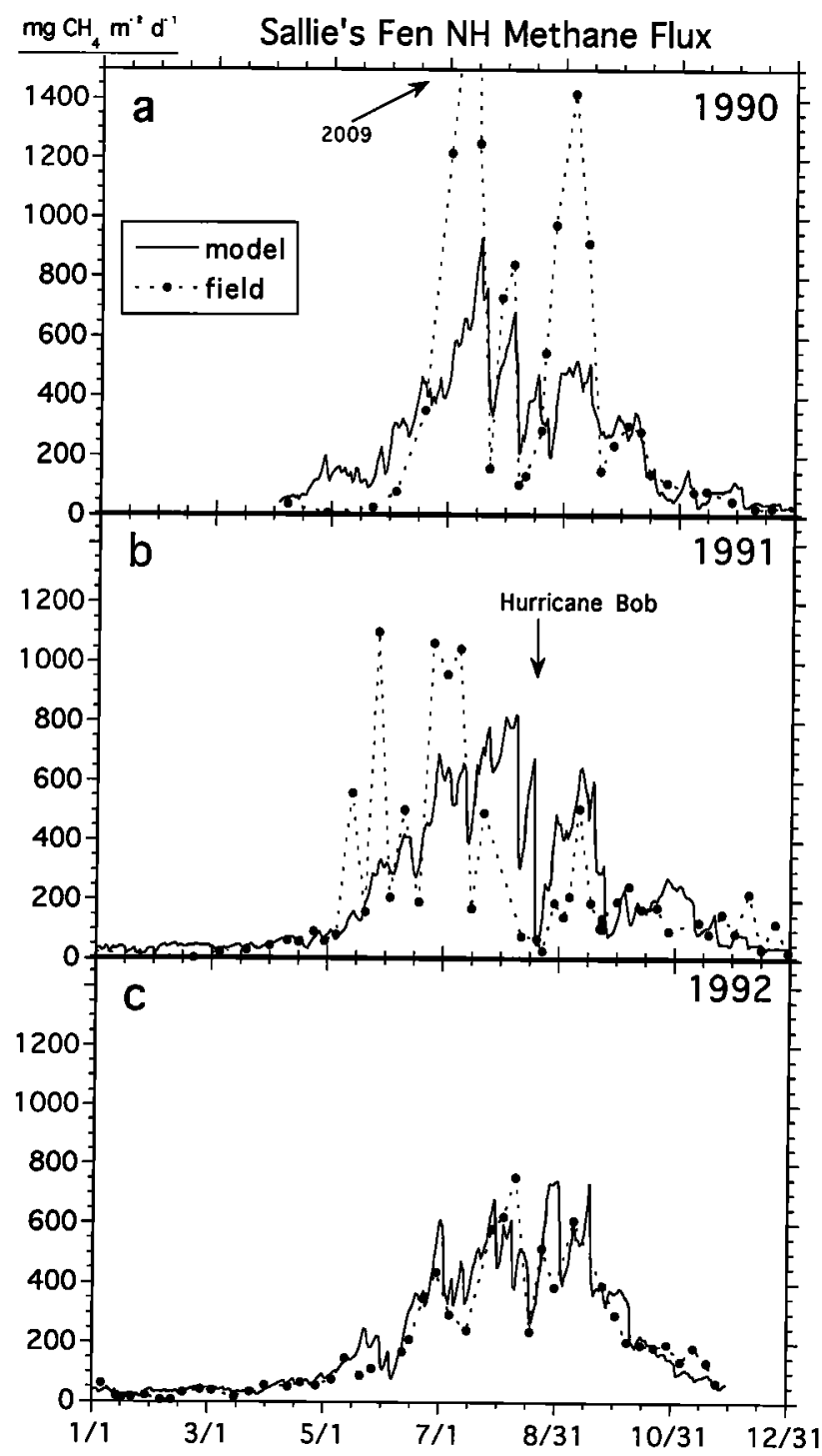

Figure 6. Field methane flux values (means of several chambers) and model simulation using the multiple regression (equation (3)) for (a) 1990, (b) 1991, and (c) 1992 (see text for model description). Model flux values were calculated by simulating the peat temperature and DTWT, keeping track of WRP, and using the empirical relationships derived from the field data. Only about one-half of the field data were used to develop the regression (see Figure 2). 

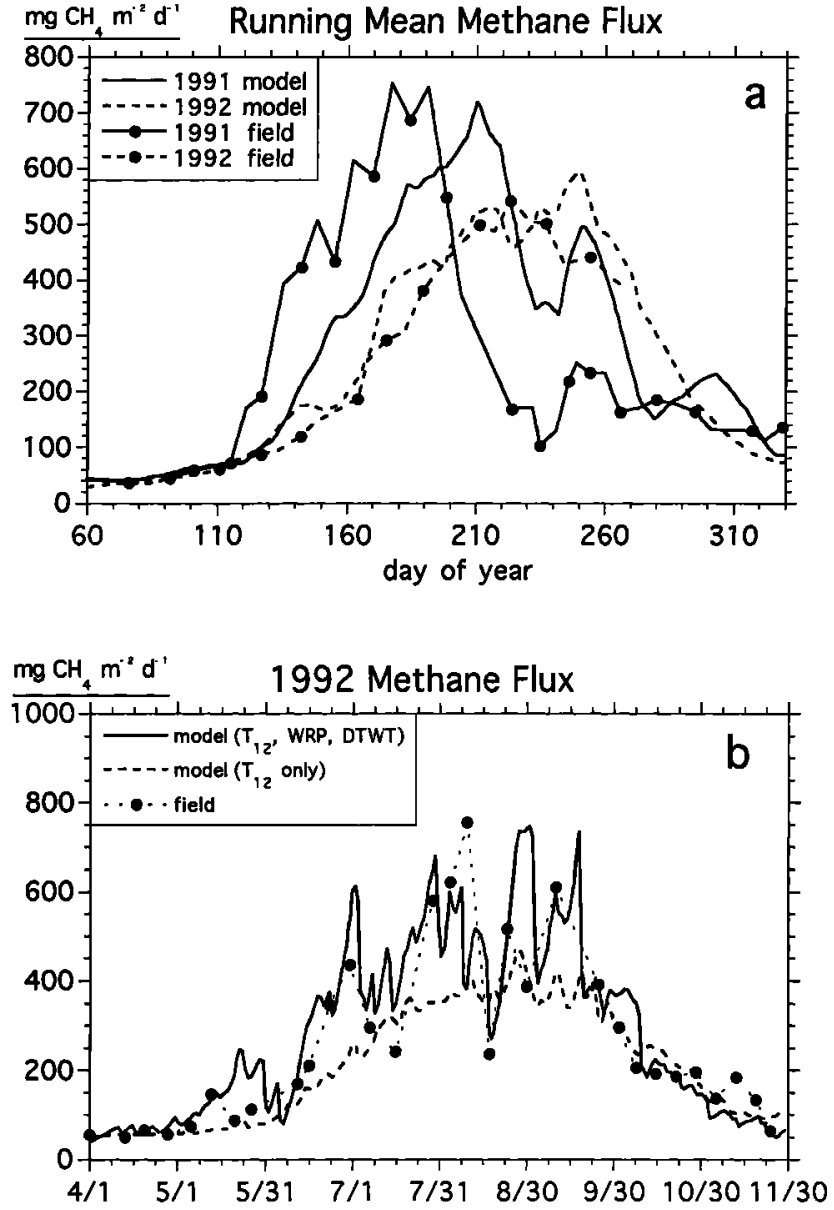

Figure 7. (a) Smoothed methane fluxes for 1991 (solid line) and 1992 (dashed line). Field results (with solid circles) are five sampling date running means (roughly \pm 2 weeks); model results are 23-day running means ( \pm 11 days). Spring 1991 was much warmer than 1992. Very heavy rains occurred in August and September 1991. Rapid onset of high flux and the higher peak fluxes in 1991 appeared to be temperature related, while heavy rains seemed to suppress fluxes later that summer (the smoothing extended this influence back into late July). (b) Field and model methane fluxes for the biologically active season of 1992 (as in Figure 6). Model results are for two regressions, one using $12-\mathrm{cm}$ peat temperature, DTWT, and WRP (solid line) and the other using just $12-\mathrm{cm}$ peat temperature (dashed line). The high degree of variability observed in the field was better captured by the multiple regression line, suggesting that precipitation patterns played an important role in summer season methane flux variability.

measurements (average of three to four chambers) for the entire time series (Figure 6).

Methane fluxes simulated with the multiple regression using peat temperature, DTWT, and WRP captured the seasonality of methane flux; this effect was dominated by the seasonal temperature signal. Significant interannual variability was evident between 1991 and 1992 (Figure 7a). Fluxes increased much more rapidly in the early summer of 1991 and reached a higher rate than in 1992. Late summer and fall fluxes in 1991 were suppressed by heavy rains (Hurricane
Bob in August and nearly twice normal rains in September). The model captured these features to some degree. Simulated fluxes rose faster in 1991 but not as fast as observed in the field. Simulated peak fluxes were higher in 1991 than 1992. The suppression of fluxes by precipitation was not as dramatic in the model as was observed. In August 1991, rains associated with Hurricane Bob (a 100-year storm) appear to have suppressed fluxes for at least 3 weeks, while in the model the WRP effect of any storm can only last 5 days, so model fluxes recovered much more rapidly (Figure 7a).

The timing of much of the observed intra-annual variability was present in the simulated fluxes (Figure 6), suggesting that weather patterns play an important role in short-term flux variability at Sallie's Fen. For the late summer of 1991 and for 1992 the multiple regression model reproduced the magnitude of the fluctuations as well, but for 1990 and early and midsummer of 1991, observed fluctuations were generally much larger than the model generated. The very high fluxes in July 1990 occurred just after a beaver dam had been removed from the fen. The water had probably been relatively stagnant while the dam was present, and then the water table rapidly dropped by $\sim 30-40 \mathrm{~cm}$. This may have been a case of rapid lowering of hydrostatic pressure generating a flux pulse in July 1990 [Moore et al., 1990]. The high fluxes of late summer 1990 and early summer 1991 are more difficult to explain. They may reflect other sources of variability or may be related to longer-term dynamics of methane production, storage, and release from the continually submerged, deep peat.

Using the temperature regression alone (see (1)), some short-term variability was present, but simulated fluxes were much smoother and some of the oscillations were not present (Figure 7b). In addition, the many low fluxes observed during midsummer reduced the strength of the temperature response in the temperature only regression, so simulated midsummer fluxes were low. The role of precipitation and hydrology in short-term variability is apparent.

\section{Conclusions}

Temporal variability in methane flux from northern peatlands may be qualitatively and quantitatively correlated with climatic and weather variables. Peat temperature alone can describe the strong seasonal variation in flux signal observed in all full year studies of northern peatlands. Variation in this seasonal signal from one year to the next is caused, in part, by variability in weather from one year to the next. This may be particularly true of the onset (and probably the decline as well) of the biologically active warm season, as was seen when comparing April and May 1991 flux and temperatures against April and May 1992 (see Figures 1a and 7). If peak fluxes in midsummer are limited by nonclimatic factors (e.g., substrate supply), then a change in season length associated with any climatic warming may have the strongest effect on high-latitude methane fluxes. Understanding the behavior of these ecosystems in the month or two following thaw may be crucial to predicting the impacts of climate change.

There is a high degree of variability in methane flux during the warm season observed in this and other studies [e.g. Dise, 1993; Whalen and Reeburgh, 1992; Shurpali et al., 1993; 
Windsor et al., 1992; Moore et al., 1990], which presents a challenge to any assessment of annual methane flux from northern peatlands. The data from Sallie's Fen indicate that this variability was due, in part, to weather patterns, including the effect of precipitation suppressing methane fluxes for several subsequent days. Since weather fluctuates rapidly and aperiodically throughout the summer, an experimental design of weekly flux measurements is not an effective way to examine these effects. A more detailed study, perhaps with automated chambers for very frequent sampling over several weeks, is necessary. Weekly measurements, however, are a common experimental design, and most seasonal flux estimates are based on weekly (or less frequent) measurements. For sites where the timing and magnitude of precipitation is important (as the Sallie's Fen data suggest), design of field campaigns should take this into account. It is clear that in systems like Sallie's Fen one or a few flux measurements in a summer may give a very poor indication of what the season's integrated flux would be. It is also clear from the data presented that other factors (besides temperature and precipitation) were involved in controlling the magnitude of this rapid variability.

Modeling the temperature dynamics of a peat profile can be accomplished with traditional soil physics techniques and appropriate thermal properties for the peat material. Efforts to develop a traditional soil physics model of peat soil water profile dynamics were hampered by the lack of adequate data on the hydraulic properties of a peat profile. However, the simple bucket model developed in this study shows promise for simulating water table dynamics in peatlands without a strong interaction with the surrounding watershed (i.e., bogs). The hydrology of the peat profile in a fen, where hydrologic interactions with the regional watershed at times dominate the system, will require a more complete watershed model. The linking of a model of peat soil climate and a process-based model of biogeochemical processes within a peat profile will allow for the assessment of the impact of anticipated climate change on methane fluxes and the general carbon balance of northern peatlands.

Acknowledgments. We would like to thank Tim Finnegan, Kirsten Klemm, and Matt Osborn for their sterling work in the field and lab; Bob Adams for local weather data from the NH Climatological Office, Durham, NH; and Bob Harriss for ideas, suggestions, and discussions. We also thank Jeff Foggman for continued access to the Sallie's Fen field site. The modeling component of this work was supported by a NASA Graduate Student Researcher Program Fellowship to S.F. for his dissertation work at the University of New Hampshire; the field component, by grants from the NASA Interdisciplinary and Terrestrial Ecology Programs to P.C. This manuscript was much improved by the careful and critical reading and useful recommendations of three anonymous reviewers.

\section{References}

Bartlett, K.B., and R.C. Harriss, Review and assessment of methane emissions from wetlands, Chemosphere, 26, 261-320, 1993.

Bartlett, K. B., P. M. Crill, R. L. Sass, R. C. Harriss, and N. B. Dise, Methane emissions from tundra environments in the YukonKuskokwim Delta, Alaska, J. Geophys. Res., 97, 16,645-16,660, 1992.

Baskerville, G.L., Use of logarithmic regression in the estimation of plant biomass, Can. J. For. Res., 2, 49-53, 1972.
Beauchamp, J.J., and J.S. Olson, Corrections for bias in regression estimates after logarithmic transformation, Ecology, 54, 1403-1407. 1973.

Boelter, D., Water storage properties of several peats in situ, Soil Sci. Soc. Am. Proc., 28, 433-435, 1964.

Boelter, D., Physical properties of peats related to degree of decomposition, Soil Sci. Soc. Am. Proc., 33, 606-609, 1969.

Boelter, D., and E. Verry, Peatland and Water in the Northern Lake States, Gen. Tech. Rep. NC-31, U.S. Dep. of Agric., For. Serv., Washington, D.C., 1977.

Bras, R., Hydrology: An Introduction to Hydrologic Science, AddisonWesley, Reading Mass., 1990.

Chason, D.B., and D.I. Siegel, Hydraulic conductivity and related physical properties of peat, Lost River Peatland, northern Minnesota, Soil Sci., 142, 91-99, 1986.

Cicerone, R. J., and R. S. Oremland, Biogeochemical aspects of atmospheric methane, Global Biogeochem. Cycles, 2, 299-328, 1988.

Clymo, R., The limits of peat bog growth, Philos. Trans. R. Soc. London, $B, 303,605-654,1984$.

Crill, P. M., K. B. Bartlett, R. C. Harriss, E. Gorham, E. S. Verry, D. I. Sebacher, L. Madzar, and W. Sanner, Methane flux from Minnesota peatlands, Global Biogeochem. Cycles, 2, 371-384, 1988.

Crill, P.M., R.C. Harriss, and K.B. Bartlett, Methane fluxes from terrestrial wetland environments, in Microbial Production and Consumption of Greenhouse Gases: Methane, Nitrogen Oxides, and Halomethanes, edited by J.E. Rogers and W.B. Whitman, pp. 91-110, American Society for Microbiology, Washington D.C., 1991.

Dise, N., Methane emission from Minnesota peatlands: spatial and seasonal variability, Global Biogeochem. Cycles, 7, 123-142, 1993.

Dise, N., E. Gorham, and E. Verry, Environmental factors controlling methane emissions from peatlands in northern Minnesota, $J$. Geophys. Res., 98, 10,583-10,594, 1993.

Dunne, T., and L. Leopold, Water in Environmental Planning, W. H. Freeman, New York, 1978.

Fan, S. M., S. C. Wofsy, P. S. Bakwin, D. J. Jacob, S. M. Anderson, P. L. Kebabian, J. B. McManus, C. E. Kolb, and D. R. Fitzjarrald, Micrometeorological measurements of $\mathrm{CH}_{4}$ and $\mathrm{CO}_{2}$ exchange between the atmosphere and subarctic tundra, J. Geophys. Res., 97, 16,627-16,644, 1992.

Farouki, O., Thermal Properties of Soils, CRREL Monograph \#81-1, US Army Corps of Engineers, Cold Reg. Res. and Eng. Lab., Hanover, NH, 1981.

Frolking, S., Modeling soil climate controls on the exchange of trace gases between the terrestrial biosphere and the atmosphere, Ph.D. thesis, 231 pp., Univ. of N. H., Durham, 1993.

Guertin, D.P., P.K. Barten, and K.H. Brooks, The peatland hydrologic impact model: Development and testing, Nord. Hydrol., 18, 79-100, 1987.

Guymon, G.L., and J.N. Luthin, A coupled heat and moisture transport model for arctic soils, Water Resour. Res., 10, 995-1001, 1974.

Hillel, D., Fundamentals of Soil Physics, Academic, San Diego, Calif., 1980.

Huyakorn, P., and G. Pinder, Computational Methods in Subsurface Flow, Academic, San Diego, CA, 1983.

Lunardini, V., Heat Transfer in Cold Climates, Van Nostrand Reinhold, New York, 1981.

Lunardini, V., Heat Conduction with Freezing and Thawing, CRREL Monogr. 88-1, U.S. Army Corps of Eng. Cold Reg. Res. and Eng. Lab., Hanover, N.H., 1988.

Moore, T. R., N. Roulet, and R. Knowles, Spatial and temporal variations of methane flux from subarctic/northern boreal fens, Global Biogeochem. Cycles, 4, 26-49, 1990.

Morrissey, L. A., and G. P. Livingston, Methane emissions from Alaska arctic tundra: an assessment of local spatial variability, J. Geophys. Res., 97, 16,661-16,670, 1992.

Press, W., B. Flannery, S. Teukolsky, and W. Vetterling, Numerical 
Recipes: The Art of Scientific Computing, Cambridge University Press, New York, 1986.

Romanov, V., Hydrophysics of Bogs (translated from Russian by N. Kaner), Israel Program for Scientific Translations, Jerusalem, 1968.

Roulet, N., R. Ash, and T. Moore, Low boreal wetlands as a source of atmospheric methane, J. Geophys. Res., 97, 3739-3749, 1992.

Roulet, N.T., S. Hardill, and N. Comer, Continuous measurement of the depth of water table (inundation) in wetlands with fluctuating surfaces, Hydrol. Processes, 5, 399-403, 1991.

Rouse, W., Microclimate at arctic tree line. I. Radiation balance of tundra and forest, Water Resour. Res., 20, 57-66, 1984.

Rouse, W., P. Mills, and R. Stewart, Evaporation at high latitudes, Water Resour. Res., 13, 909-914, 1977.

Rouse, W.R., S.G. Hardill, and P. Lafleur, The energy balance in the coastal environment of the James Bay and Hudson Bay during the growing season, J. Climatol., 7, 165-179, 1987.

Sebacher, D. I., R. C. Harriss, K. B. Bartlett, S. M. Sebacher, and S. S. Grice, Atmospheric methane sources: Alaskan tundra bogs, an alpine fen, and a subarctic boreal marsh, Tellus, Ser. B, 38, 1-10, 1986.

Shurpali, N.J., S.B. Verma, R.J. Clement, and D.P. Billesbach, Seasonal distribution of methane flux in a Minnesota peatland measured by eddy correlation, J. Geophys. Res., 98, 20,649-20,655, 1993.

Svensson, B. H., and T. Rosswall, In situ methane production from acid peat in plant communities with different moisture regimes in a subarctic mire, Oikos, 43, 341-450, 1984.
Torn, M., and F.S. Chapin III, Environmental and biotic controls over methane flux from arctic tundra, Chemosphere, 26, 357-368, 1993 :

Waelbroeck, C., Climate-soil processes in the presence of permafrost: A systems modelling approach. Ecol. Modell., 69, 185-225, 1993.

Whalen, S., and W. Reeburgh, A methane flux transect along the transAlaskan pipeline haul road, Tellus, Ser. B, 42, 237-249, 1990.

Whalen, S., and W. Reeburgh, Interannual variations in tundra methane emissions: A four-year time series at fixed sites, Global Biogeochem. Cycles, 6, 139-159, 1992.

Whiting, G.J., and J.P. Chanton, Primary production control of methane emission from wetlands, Nature, 364, 794-795, 1993.

Williams, P.J., and M.W. Smith, The Frozen Earth: Fundamentals of Geocryology, Cambridge University Press, New York, 1989.

Windsor, J., T.R. Moore, and N.T. Roulet, Episodic fluxes of methane from subarctic fens, Can. J. Soil Sci., 72, 441-452, 1992.

P. Crill and S. Frolking, Complex Systems Research Center, Institute for the Study of Earth, Oceans, and Space, Morse Hall, University of New Hampshire, Durham, NH 03824-3525. (e-mail: patrick@kaos.unh.edu; stevef@kaos.unh.edu)

(Received March 14, 1994; revised June 27, 1994; accepted July $7,1994$. 